\title{
Classic Galactosemia Presenting with Unilateral Peters' Anomaly
}

\author{
Hadeel Faras Fayka Al-Raqum Dina Ramadan \\ Department of Pediatrics, Al-Sabah Hospital, Ministry of Health, Kuwait
}

\section{Key Words}

Corneal opacity $\cdot$ Galactosemia $\cdot$ Peters' anomaly

\begin{abstract}
Objective: To report a case of classic galactosemia that presented with a rare ocular finding, Peters' anomaly. Clinical Presentation and Intervention: A neonate, born to firstdegree healthy cousins, presented with persistent vomiting, failure to thrive, lethargy, and jaundice. Corneal opacity was noticed in the left eye. Hydration and empiric antibiotics were started after collection of the required blood work, which included both a septic and a metabolic workup. A deficiency in erythrocyte galactose-1-phosphate uridyltransferase was found, and this led to the diagnosis of classic galactosemia and the elimination of galactose from the diet. Furthermore, a diagnosis of left unilateral Peters' anomaly was made after examination by a pediatric ophthalmologist. The patient was discharged in stable condition and followup visits were scheduled with the metabolic clinic, a dietician, and the pediatric ophthalmologist. Conclusion: This was a case of classic galactosemia presenting with Peters' anomaly, probably due to autosomal recessive disorder from first-degree consanguinity marriage.
\end{abstract}

Copyright $\odot 2010$ S. Karger AG, Basel
(C) 2010 S. Karger AG, Basel

$1011-7571 / 10 / 0194-0324 \$ 26.00 / 0$

Fax +4161306 1234

E-Mail karger@karger.ch

www.karger.com
Accessible online at: www.karger.com/mpp

\section{Introduction}

Galactosemia is caused by an inborn error of carbohydrate metabolism. Classic galactosemia is a potentially lethal illness that exhibits an acute onset and presentation during the 1st week of life following the introduction of a galactose-containing diet [1]. It is an autosomal recessive disorder with an incidence of 1:40,000 to 1:60,000 in Caucasian populations and is caused by a mutation in the GALT gene in the short arm of chromosome 9, leading to a deficiency in the enzyme galactose-1-phosphate uridyltransferase $[1,2]$. If left untreated, galactose-1-phosphate accumulates and can reach toxic levels, causing damage to the liver, brain, and other vital organs $[1,3]$. Diagnosis and treatment of this disorder should be performed as early as possible in order to prevent neonatal death and to minimize the possibility of any permanent liver or brain damage $[1,4]$.

The presence of cataracts has been reported as the main ophthalmologic defect associated with classic galactosemia [4]. Here, we report a case of classic galactosemia in the absence of cataract but presenting with unilateral Peters' anomaly. 


\section{Case Report}

A 24-day-old Kuwaiti male neonate presented with a history of persistent vomiting, failure to thrive, lethargy, and jaundice. He was born by full-term normal vaginal delivery, and the birth weight was $3,500 \mathrm{~g}$ (50th percentile). The baby was breast-fed since birth, and the vomiting started around the 3rd day of life. The vomiting was non-bilious, persistent, and followed each feeding. The mother switched from breast-feeding to artificial feeds at 2 weeks of age with no improvement. The baby started to lose weight and became lethargic. There was no history of fever, rash, diarrhea, or sick contact. The parents were first-degree cousins; both were fully healthy and did not have eye abnormalities. The baby was their first child. On examination, the baby was noted to be emaciated, lethargic, and jaundiced. His admission weight was less than his birth weight, at only 3,200 g (5-10th percentile). He was afebrile with stable vital signs. Corneal opacity was noticed in his left eye. Abdominal examination revealed a palpable liver edge; the rest of the examination was unremarkable. Hydration and empiric antibiotics were started after collection of the required blood work, which included both a septic and metabolic workup. The investigations showed normal blood cell and reticulocyte counts. Serum glucose, electrolytes, urea, and creatinine levels were within normal limits. Liver function tests demonstrated a total billirubin level of $127.8 \mu \mathrm{mol} / \mathrm{l}$, with an elevated direct bilirubin level: $92 \mu \mathrm{mol} / \mathrm{l}$, elevated serum alkaline phosphatase: $592 \mathrm{U} / 1$ (normal range 50-136 U/1), elevated alanine aminotransferase: $207 \mathrm{U} / \mathrm{l}$ (normal range 30-65 U/l), and low albumin: $29 \mathrm{~g} / \mathrm{l}$ (normal range 34-50 g/l). The coagulation profile revealed a prothrombin time of $18 \mathrm{~s}$ (normal range 10-15 s), a partial thromboplastin time of $58 \mathrm{~s}$ (normal range 31-54 s), and an international normalized ratio of 1.58 . No growth of microorganisms was observed in blood, urine, or stool cultures. Virology study for congenital infections - toxoplasmosis, rubella, cytomegalovirus and herpes simplex virus (TORCH screen) - was negative. An abdominal ultrasound revealed normal findings. Blood gas analysis, serum ammonia, serum lactate, plasma, and urine amino acids, as well as tests for urinary organic acids showed no significant abnormalities. A test for urine reducing substance was positive in several urine specimens. This prompted further investigations to rule out inborn errors of carbohydrate metabolism. A deficiency in erythrocyte galactose-1-phosphate uridyltransferase was confirmed on the 5th day of admission resulting in the diagnosis of classic galactosemia. Galactose-free formula was started, and this resulted in resolution of the vomiting, weight gain, restoration of normal activity level, and normalization of the biochemical investigations during the period of hospitalization.

In addition to the metabolic workup, the patient was evaluated by a pediatric ophthalmologist, who performed a slit-lamp biomicroscopy and fundus examination, revealing the presence of a left central corneal opacity that extended to the periphery, with adherent iris strands to the corneal endothelium. Ultrasound of the orbit showed a normal posterior segment, but the size of the left globe was noted to be smaller than the right one. There was no evidence of cataract, and the fundus and intraocular pressure were normal. No abnormalities were detected on examination of the right eye. A diagnosis of left unilateral Peters' anomaly was established.

The patient was discharged at 44 days of age in stable condition while being fed a galactose-free diet. The discharge weight was
$4,200 \mathrm{~g}$ (50th percentile). Follow-up visits were scheduled with the metabolic clinic, a dietician, and the pediatric ophthalmologist. A family history of galactosemia was disclosed later during the follow-up visits. Molecular genetic testing was performed and revealed two copies of Q188R, which represents a classic galactosemia mutation. However, other genetic mutations, including PAX6, PITX2, FOXC1, CYP1B1 and RIEG1 were not done due to the lack of availability of a facility for testing them.

\section{Discussion}

We present a case of a neonate with a non-specific presentation of vomiting, failure to thrive, lethargy, and prolonged jaundice. Investigations revealed evidence of conjugated hyperbilirubinemia and early hepatic dysfunction. The diagnosis of galactosemia was suspected on clinical grounds and because of the finding of a reducing substance present in the urine. The diagnosis was confirmed by measurement of galactose-1-phosphate uridyltransferase enzyme activity in erythrocytes. In addition, this patient carried a $Q 188 R$ mutation, which accounts for $60 \%$ of galactosemia alleles in the Caucasian population. This is considered a severe mutation and results in a lack of galactose-1-phosphate uridyltransferase activity [2].

Cataracts are the main eye defect associated with classic galactosemia $[3,4]$. Of interest in the present case was the finding of Peters' anomaly, which is a rare congenital anterior segment dysgenesis that is characterized by central corneal opacity with irido-corneal adhesions at the periphery of the opacity [5]. This anomaly is bilateral in $80 \%$ of cases, with the rest being unilateral similar to the presented case $[6,7]$. The pathogenesis of Peters' anomaly is related to abnormal migration of neuronal crest cells [8]. This mechanism of pathogenesis differs from that of galactosemic cataract, which is proposed to be related to the accumulation of galacticol, a product of the alternate galactose pathway [3]. Sporadic, autosomal dominant and autosomal recessive forms of Peters' anomaly have been reported with a small number of cases described in association with PAX6, PITX2, FOXC1, CYP1B1 and RIEG1 mutations [6, 7, 9-11]. However, the majority of Peters' anomaly cases have no identifiable cause [7]. Peters' anomaly is a serious ophthalmologic problem that requires follow-up for refraction, treatment of amblyopia, and measurement of intraocular pressure; it may be associated with other ocular anomalies, including microphthalmia, which was present in our case $[8,12]$. In the present case, the first-degree consanguinity supports a possible autosomal recessive inheritance of Peters' anomaly. 


\section{Conclusion}

This was a case of classic galactosemia presenting with Peters' anomaly, probably due to autosomal recessive disorder from first-degree consanguinity marriage.

\section{Acknowledgment}

We would like to thank the Biochemistry Department in the Faculty of Medicine, Kuwait University, for its help in the diagnosis of this case. Dr. Abdul-Mutalib Behbehani, Pediatric Ophthalmologist, Al-Bahar Eye Center, Kuwait, is thanked for his valuable contribution in reviewing the manuscript.

\section{References}

1 Bosch AM: Classical galactosaemia revisited. J Inherit Metab Dis 2006;29:516-525.

$\checkmark 2$ Item C, Hagerty BP, Mühl A, Greber-Platzer S, Stöckler-Ipsiroglu S, Strobl W: Mutations at the galactose-1-p-uridyltransferase gene in infants with a positive galactosemia newborn screening test. Pediatr Res 2002;51:511516.

3 Beigi B, O’Keefe M, Bowell R, Naughten E, Badawi N, Lanigan B: Ophthalmic findings in classical galactosaemia - prospective study. Br J Ophthalmol 1993;77:162-164.

$\checkmark 4$ Wilson WA: Ocular findings in several metabolic diseases. Calif Med 1969;111:446449.

$>5$ Haddad AM, Greenfield DS, Stegman Z, Liebmann JM, Ritch R: Peter's anomaly: diagnosis by ultrasound biomicroscopy. Ophthalmic Surg Lasers 1997;28:311-312.
6 Vincent A, Billingsley G, Priston M, Glaser T, Oliver E, Walter M, Ritch R, Levin A, Heon E: Further support of the role of CYP1B1 in patients with Peters anomaly. Mol Vis 2006;12:506-510.

7 Doward W, Perveen R, Lloyd IC, Ridgway AE, Wilson L, Black GC: A mutation in the RIEG1 gene associated with Peters' anomaly. J Med Genet 1999;36:152-155.

8 Casteels I, Devriendt K: Unilateral Peters' anomaly in a patient with DiGeorge syndrome. J Pediatr Ophthalmol Strabismus 2005;42:311-313.

9 Berker N, Alanay Y, Elgin U, Volkan-Salanci B, Simsek T, Akarsu N, Alikasifoglu M: A new autosomal dominant Peters' anomaly phenotype expanding the anterior segment dysgenesis spectrum. Acta Ophthalmol 2009;87:52-57.
10 Hanson IM, Fletcher JM, Jordan T, Brown A, Taylor D, Adams RJ, Punnett HH, van Heyningen V: Mutations at the PAX6 locus are found in heterogeneous anterior segment malformations including Peters' anomaly. Nat Genet 1994;6:168-173.

11 Honkanen RA, Nishimura DY, Swiderski RE, Bennett SR, Hong S, Kwon YH, Stone EM, Sheffield VC, Alward WL: A family with Axenfeld-Rieger syndrome and Peters anomaly caused by a point mutation (Phe112Ser) in the FOXC1 gene. Am J Ophthalmol 2003;135: 368-375.

12 Mayer UM: Peters' anomaly and combination with other malformations (series of 16 patients). Ophthalmic Paediatr Genet 1992; 13:131-135. 